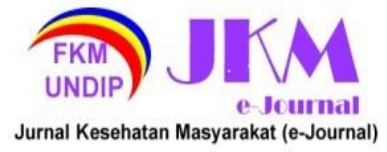

\section{ANALISIS STATUS MUTU AIR SUNGAI KOTA BOGOR TAHUN 2015-2019 BERDASARKAN SEGMENTASI DAN MUSIM}

\author{
Lailatussyifah Nasution ${ }^{1 *}$, Yusniar Hanani Darundiati ${ }^{2}$, Suhartono ${ }^{2}$ \\ ${ }^{1}$ Peminatan Kesehatan Lingkungan, Fakultas Kesehatan Masyarakat Universitas Diponegoro \\ ${ }^{2}$ Bagian Kesehatan Lingkungan, Fakultas Kesehatan Masyarakat Universitas Diponegoro \\ ${ }^{*}$ Corresponding author: syifanasution23@gmail.com
}

\title{
ABSTRACT
}

The development of Bogor city as a buffer zone for the capital has made its water quality decrease. The river water quality has never reached the Water Quality Index (WQI) set for 2015-2019. This study aims to analyze the difference of Bogor river water quality value in 2015-2019 based on segmentations and seasons. Storet and Pollution Index method were used to measure the value of the quality status. Based on statistical tests results, the value between upstream, middle, and downstream both in rainy ( $p$ value = 0,252 for Storet method, $p$ value $=0,520$ for Pollution Index method) and dry seasons ( $p$ value $=0,817$ for Storet method, $p$ value $=0,230$ for Pollution Index method) did not differ significantly. The value based on Storet method between rainy and dry seasons differed significantly, both in upstream ( $p$ value $=0,008$ ) and middlestream ( $p$ value $=0,001$ ) but did not differ significantly in downstream ( $p$ value $=0,066$ ). Based on Pollution Index method, the value between rainy and dry seasons did not differ significantly in upstream ( $p$ value $=0,961$ ) but differed significantly in middlestream ( $p$ value $=0,028)$ and downstream ( $p$ value $=0,031) . B O D$, total phosphate, and nitrite were dominant parameters for quality status based on segmentations, while coliform were dominant parameters for quality status based on seasons. It can be concluded that the value of water quality status in Bogor city between upstream, middle, and downstream do not differ significantly and tends to be worse in dry season.

Key words: Quality status value, Storet, Pollution Index, segmentations, seasons

\section{PENDAHULUAN}

Kota Bogor merupakan wilayah yang strategis untuk kegiatan perekonomian dan industri karena posisinya sebagai salah satu penyangga ibukota negara serta letaknya yang berdekatan dengan kota besar lainnya seperti Bandung. Kota Bogor juga tumbuh menjadi kota berbasis pemukiman. ${ }^{1} \mathrm{Di}$ sisi lain perkembangan tersebut mempengaruhi kualitas lingkungan hidup di Kota Bogor, salah satunya ekosistem sungai. Sungai mulai beralih fungsi menjadi jalur pembuangan limbah domestik dan industri, serta wilayah sempadannya mulai berkurang karena dimanfaatkan sebagai wilayah pemukiman. Akibatnya luas area sempadan sungai berkurang $30,3 \%$ dari 181,79 Ha menjadi 126,77 Ha. $^{2}$

Kota Bogor dijuluki sebagai kota hujan karena hujan yang turun hampir sepanjang tahun dan dengan intensitas yang cukup tinggi $(79-652 \mathrm{~mm}) .^{3}$ Air hujan merupakan sumber utama air sungai. Air hujan yang mengalir di wilayah pemukiman ataupun area terbangun akan menyapu zat-zat polutan di permukaan dan mengalirkannya ke dalam sungai. Curah hujan berkaitan erat dengan jenis musim di suatu wilayah. 4,5

Kota Bogor dialiri oleh sepuluh sungai yaitu Cisadane, Ciliwung, Angke, Cipakancilan, Cianten, Cidepit, Cisindangbarang, Cibalok, Ciparigi, dan Ciluar. $^{3}$ Sungai Ciliwung dan Cisadane dimanfaatkan sebagai sumber air baku untuk Perusahaan Daerah Air Minum (PDAM). Sementara sungai lainnya dimanfaatkan oleh masyarakat sekitar untuk kegiatan sehari-hari seperti air baku industri, pertanian, peternakan, dan sumber air wilayah permukiman. ${ }^{6}$ Berdasarkan data dari Bappeda Kota Bogor target Indeks Kualitas Air (IKA) Kota Bogor pada RPJMD (Rencana Pembangunan Jangka Menengah Daerah) 2015-2019 tidak pernah tercapai. ${ }^{7}$ Mengingat pentingnya fungsi sungai tersebut, perlu untuk dilakukan pemantauan kualitas air sungai secara berkala untuk mengetahui apakah peruntukannya masih layak atau tidak.

Pemantauan kualitas air sungai dapat menjadi salah satu langkah pengawasan dan pengendalian pencemaran air sungai oleh zatzat berbahaya. Selain itu dapat disusun rencana 


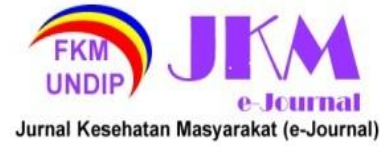

lebih lanjut guna mempertahankan atau meningkatkan kualitas air sungai agar sesuai dengan baku mutu peruntukannya sehingga tidak merugikan kesehatan masyarakat maupun lingkungan. Salah satu cara untuk mengetahui kualitas air sungai yaitu dengan perhitungan nilai status mutu air sungai. ${ }^{8}$

Ada berbagai cara untuk menentukan status mutu air sungai. Namun metode resmi yang ditetapkan oleh Pemerintah RI yaitu Indeks Pencemaran dan Storet yang dijabarkan dalam Keputusan Menteri Lingkungan Hidup Nomor 115 tahun 2003 Tentang Pedoman Penetapan Status Mutu Air.

Setiap tahunnya Dinas Lingkungan Hidup Kota Bogor melakukan pengukuran terhadap parameter kualitas air sungai dan status mutunya. Namun sampai saat ini belum pernah dilakukan penelitian yang menganalisis nilai status mutu air sungai berdasarkan segmentasi dan musim dimana DLH melakukan pengukuran parameter tersebut. Oleh karena itu penelitian ini bertujuan untuk menganalisis perbedaan nilai status mutu air sungai di Kota Bogor dari tahun 2015 hingga 2019 berdasarkan segmentasi dan musim serta menganalisis nilai parameter yang menentukan nilai status mutu tersebut berdasarkan metode Storet dan Indeks Pencemaran.

\section{METODE PENELITIAN}

Penelitian ini merupakan penelitian observasional analitik dengan pendekatan cross sectional yang menggunakan data sekunder berupa hasil pengukuran tahunan parameter kualitas air sungai oleh Dinas Lingkungan Hidup Kota Bogor tahun 2015-2019 sebagai sumber datanya. Variabel yang diteliti ialah nilai status mutu air sungai berdasarkan segmentasi dan musim yang dihitung menggunakan metode Storet serta Indeks Pencemaran.

Populasi penelitian ini yaitu hasil pengukuran tahunan seluruh parameter kualitas air sungai di wilayah Kota Bogor dari tahun 2015 hingga 2019. Sedangkan sampel penelitian yaitu data tahunan pengukuran sebelas parameter (TDS, TSS, BOD, COD, DO, pH, fosfat, nitrat, nitrit, fecal coliform, dan total coliform) air sungai di wilayah Kota Bogor dari tahun 2015 hingga 2019 oleh Dinas Lingkungan Hidup Kota Bogor. Setiap tahunnya Dinas Lingkungan Hidup Kota Bogor melakukan pengukuran parameter kualitas air sungai pada sepuluh sungai yang ada di Kota Bogor. Masing-masing sungai tersebut terdiri atas segmen yaitu hulu, tengah, dan hilir yang diukur pada musim hujan dan kemarau. Dari data tersebut diperoleh 60 nilai status mutu air sungai. Enam puluh nilai ini dianalisis lebih lanjut secara statistik.

Titik pengambilan sampel air sungai oleh Dinas Lingkungan Hidup Kota Bogor tertera pada gambar berikut ini. 

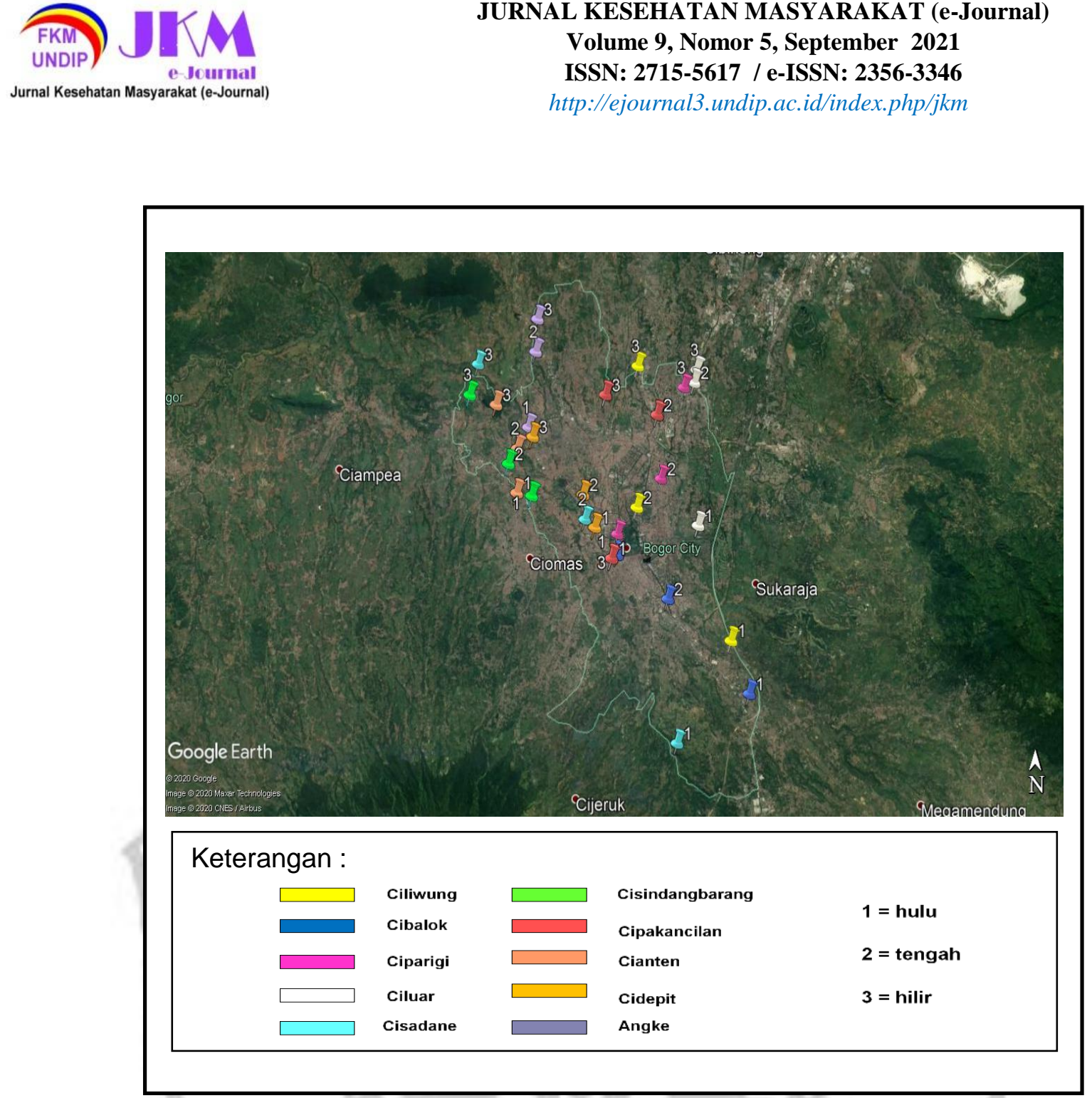

Gambar 1. Titik lokasi pengambilan sampel air sungai oleh DLH Kota Bogor ${ }^{9}$

Berikut ini merupakan cara perhitungan nilai status mutu air dengan metode Storet dan Indeks Pencemaran.

\section{Metode Storet}

Langkah-langkah perhitungan nilai status mutu dengan metode Storet yaitu ${ }^{10}$ :

a. Menentukan nilai minimum, maksimum, dan rata-rata dari setiap parameter menurut data tahun 2015-2019.

b. Memberikan skor pada masing-masing nilai maksimum, minimum, dan rata-rata parameter dengan ketentuan seperti yang ada di dalam tabel berikut.
Tabel 1 Bobot Nilai untuk Tiap Parameter pada Perhitungan Nilai Status Mutu dengan Metode Storet ${ }^{10}$

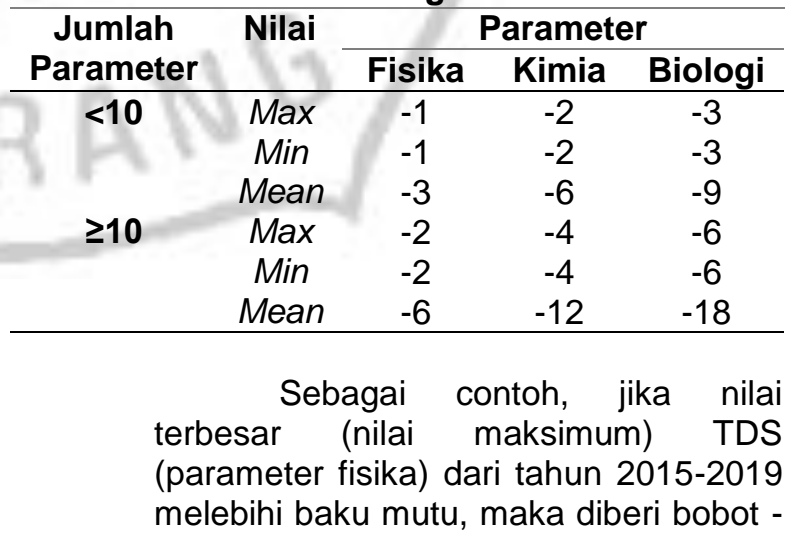




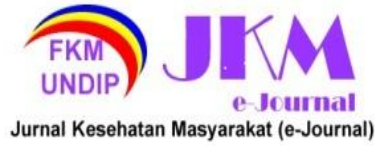

2. Jika nilai yang melebihi baku mutu adalah nilai terkecil dari tahun 20152019, maka diberi bobot -2 . Jika nilai rata-rata TDS selama tahun 2015-2019 melebihi baku mutu, maka diberi bobot 6. Kemudian hasil semua pembobotan tersebut dijumlahkan untuk memperoleh skor parameter TDS. Hal serupa dilakukan untuk seluruh parameter.

c. Menjumlahkan seluruh skor per parameter untuk memperoleh nilai Storet final.

2. Metode Indeks Pencemaran

Langkah-langkah perhitungan nilai status mutu dengan metode Storet yaitu:

a) Khusus pada penelitian ini, hasil pengukuran parameter setiap sungai selama lima tahun dihitung nilai rataratanya berdasarkan segmentasi dan musim.

b) Menghitung nilai Ci/Li setiap parameter.

c) Menghitung nilai Indeks Pencemaran dengan rumus berikut.

$$
\mathrm{PI}_{\mathrm{j}} \sqrt{\frac{\left(\mathrm{C}_{\mathrm{i}} / \mathrm{L}_{\mathrm{ij}}\right) \mathrm{M}^{2}+\left(\mathrm{C}_{\mathrm{i}} / \mathrm{L}_{\mathrm{ij}}\right) \mathrm{R}^{2}}{2}}
$$

Keterangan:

$\mathrm{Ci}=$ nilai parameter $\mathrm{i}$ hasil perhitungan

$\mathrm{Li}=$ nilai baku mutu parameter $\mathrm{i}$

$(\mathrm{Ci} / \mathrm{Li})_{\mathrm{M}}=$ nilai $\mathrm{Ci} / \mathrm{Li}$ terbesar

$(\mathrm{Ci} / \mathrm{Li})_{\mathrm{R}}=$ nilai $\mathrm{Ci} / \mathrm{Li}$ rata-rata

\section{HASIL DAN PEMBAHASAN}

Nilai Parameter Tahun 2015-2019

\section{Berdasarkan Segmentasi dan Musim}

Berikut ini merupakan grafik nilai parameter berdasarkan hasil pengukuran yang dilakukan oleh Dinas Lingkungan Hidup Kota Bogor tahun 2015-2019. Nilai yang tertera pada grafik merupakan nilai rata-rata dari seluruh sungai setiap tahunnya.

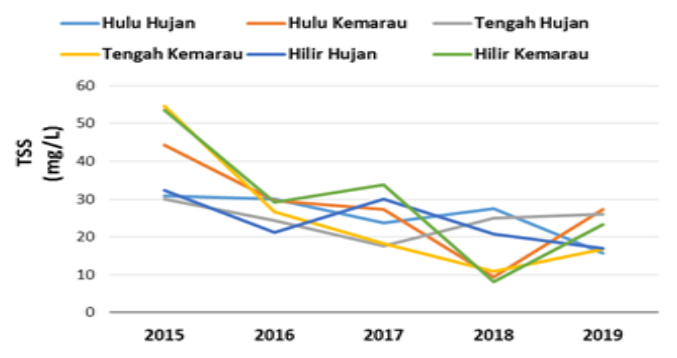

Gambar 1. Grafik nilai TSS tahun 2015-2019 berdasarkan segmentasi dan musim

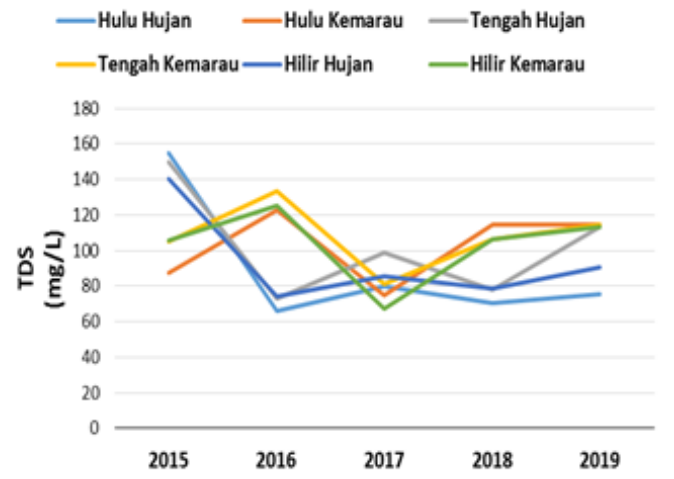

Gambar 2. Grafik nilai TDS tahun 2015-2019 berdasarkan segmentasi dan musim

Volume 9, Nomor 5, September 2021

ISSN: 2715-5617 / e-ISSN: 2356-3346

http://ejournal3.undip.ac.id/index.php/jkm

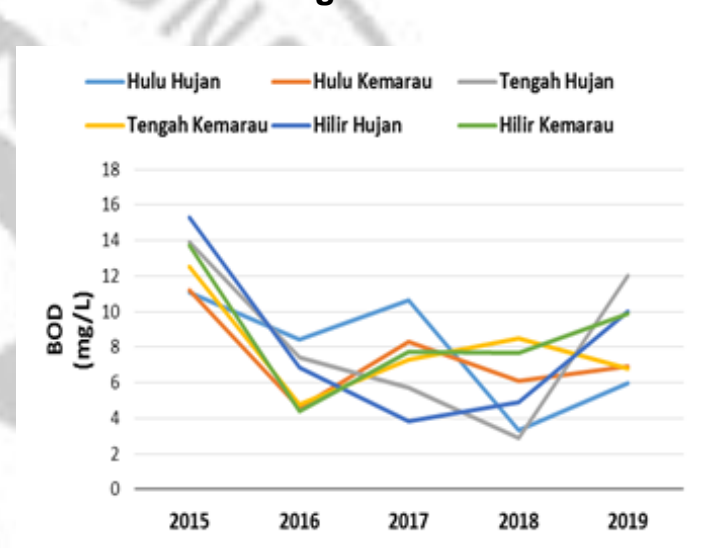

Gambar 3. Grafik nilai BOD tahun 2015-2019 berdasarkan segmentasi dan musim

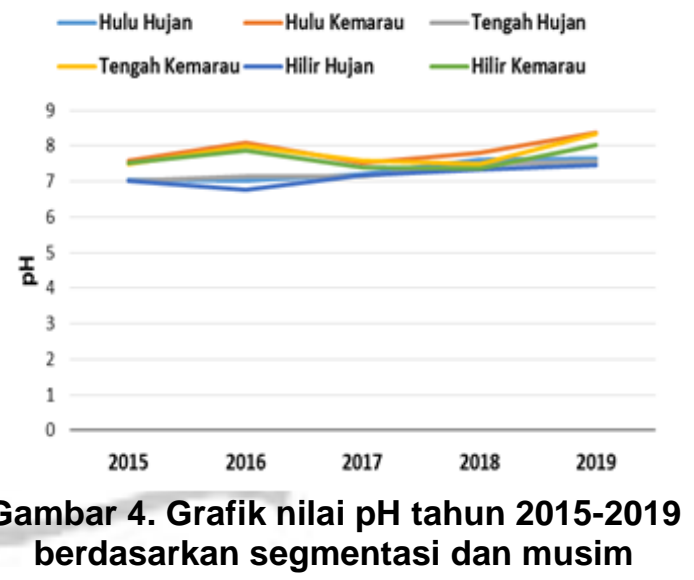



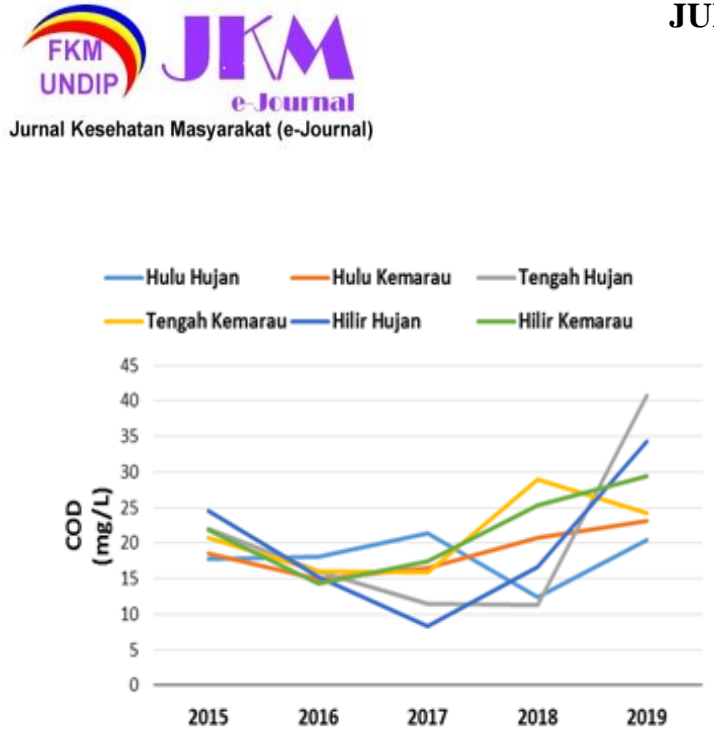

Gambar 5. Grafik nilai COD tahun 2015-2019 berdasarkan segmentasi dan musim

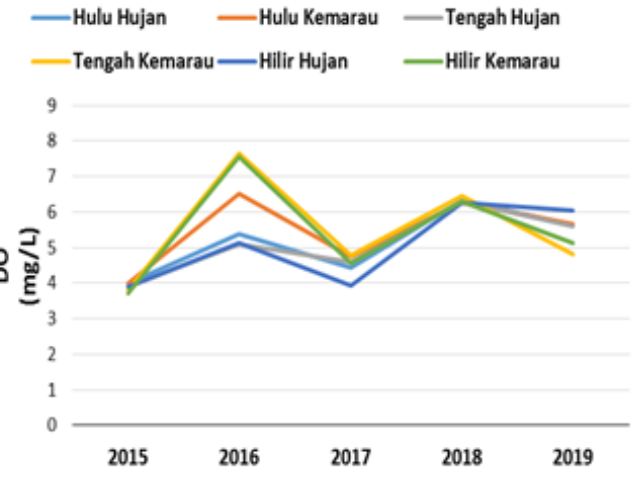

Gambar 6. Grafik nilai DO tahun 2015-2019 berdasarkan segmentasi dan musim

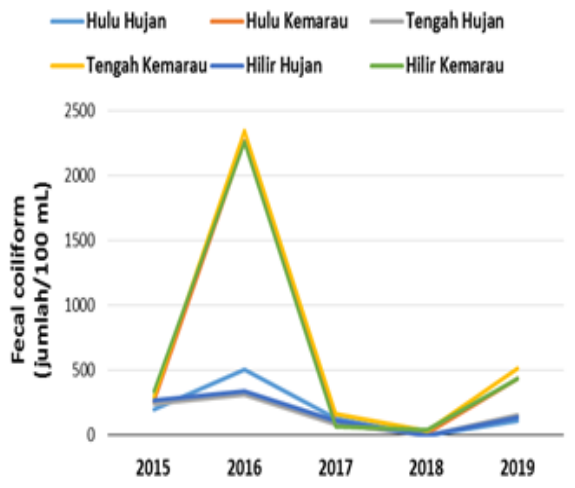

Gambar 7. Grafik nilai Fecal Coliform tahun 2015-2019 berdasarkan segmentasi dan musim
JURNAL KESEHATAN MASYARAKAT (e-Journal)

Volume 9, Nomor 5, September 2021

ISSN: 2715-5617 / e-ISSN: 2356-3346

http://ejournal3.undip.ac.id/index.php/jkm

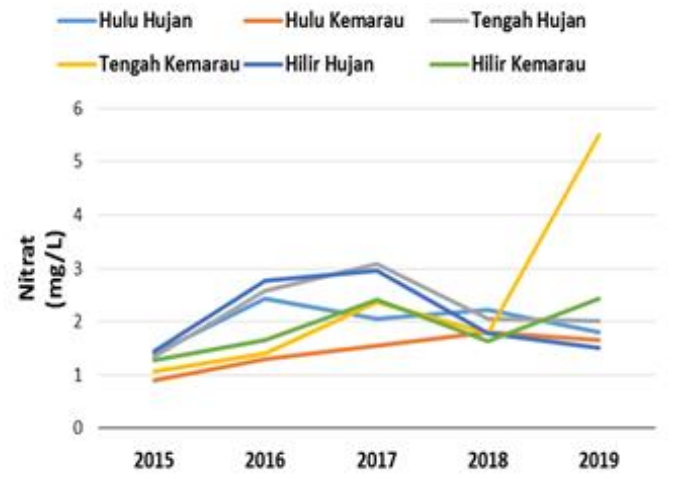

Gambar 8. Grafik nilai Nitrat tahun 2015-2019 berdasarkan segmentasi dan musim

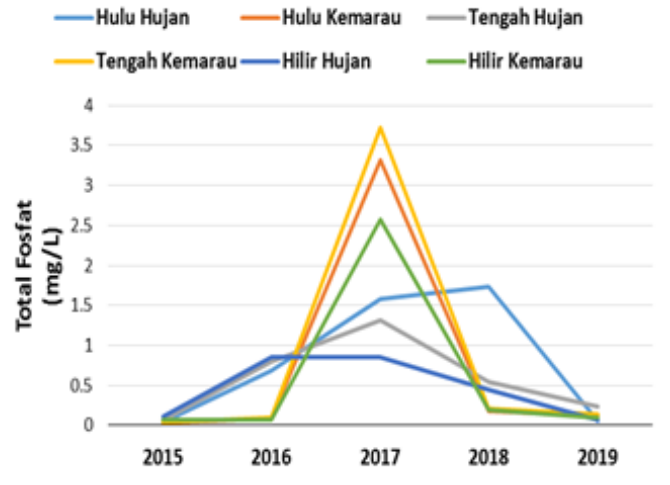

Gambar 9. Grafik nilai Total Fosfat tahun 2015-2019 berdasarkan segmentasi dan musim
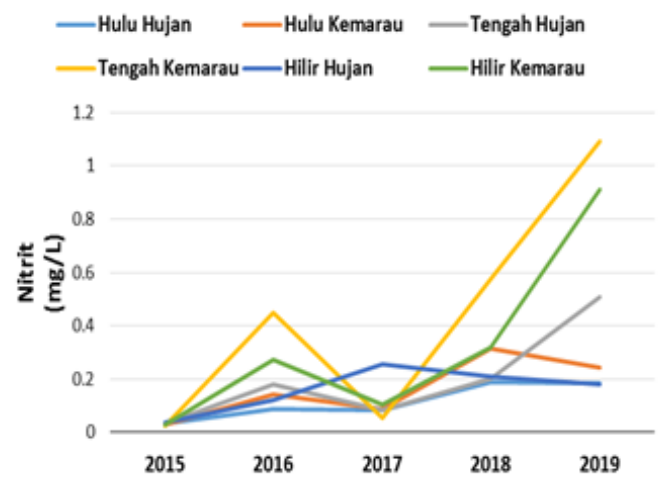

Gambar 10. Grafik nilai Nitrit tahun 2015-2019 berdasarkan segmentasi dan musim 

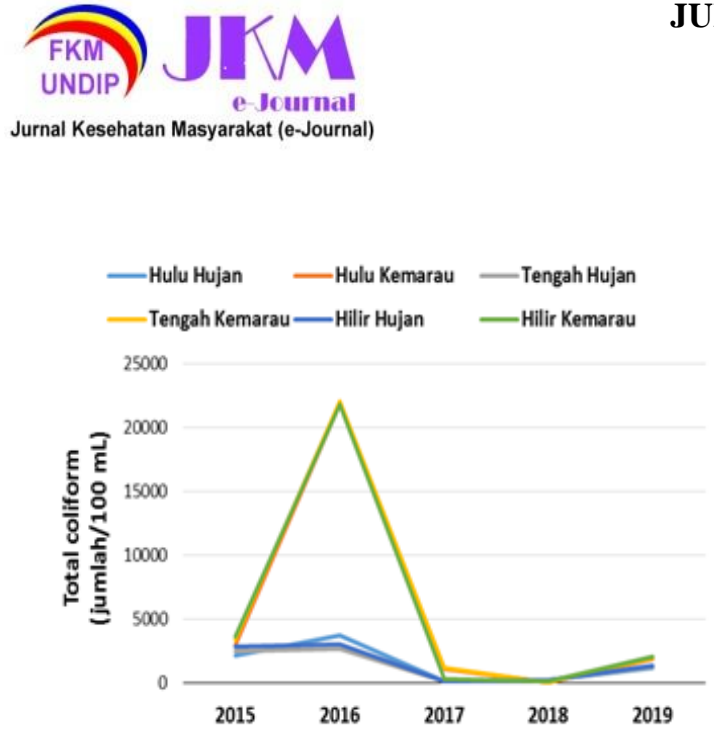

\section{Gambar 11. Grafik nilai Total Coliform tahun 2015-2019 berdasarkan segmentasi dan musim}

Berdasarkan gambar diatas diketahui bahwa nilai rata-rata parameter air sungai tahun 2015 hingga 2019 cenderung berfluktuasi antara segmen hulu, tengah, dan hilir, serta cenderung lebih tinggi pada musim kemarau dibandingkan musim hujan.

Aliran sungai dari hulu ke hilir dapat menyebabkan akumulasi bahan pencemar di bagian hilir. ${ }^{11}$ Namun sungai memiliki kemampuan untuk memulihkan keadaannya dari kondisi tercemar yang dikenal sebagai selfpurification. ${ }^{12}$ Kemampuan purifikasi setiap segmen dapat berbeda dikarenakan sifat air sungai yang dinamis. Hal ini menyebabkan konsentrasi bahan pencemar di setiap bagian segmen dapat berfluktuatif.

Curah hujan tinggi dapat menyebabkan meningkatnya laju limpasan dan volume air sungai sehingga mempermudah proses pengenceran bahan-bahan polutan. Pengenceran (dilution) adalah suatu proses untuk menurunkan konsentrasi zat terlarut dengan cara penambahan zat pelarut (dalam hal ini air). ${ }^{13}$ Pengenceran akan menurunkan konsentrasi bahan pencemar pada air sungai.

Pada musim kemarau, intensitas sinar matahari cenderung lebih tinggi dibandingkan musim hujan sehingga cenderung meningkatkan suhu permukaan air. Semakin tinggi suhu, kecepatan reaksi kimia di dalam air cenderung semakin meningkat karena suhu yang tinggi menyebabkan air dapat melarutkan lebih banyak mineral dari batuan di sekitarnya. Saat suhu tinggi, kecepatan metabolisme organisme akuatik cenderung meningkat karena sebagian besar enzim seluler lebih aktif pada suhu tinggi. ${ }^{14}$

Nilai status mutu air sungai di Kota Bogor tahun 2015-2019

a. Nilai status mutu berdasarkan segmentasi dan musim dengan metode Indeks Pencemaran

Nilai status mutu pada metode Indeks Pencemaran diperoleh berdasarkan nilai $\mathrm{Ci} / \mathrm{Li}$ masing-masing parameter. Nilai $\mathrm{Ci} / \mathrm{Li}$ adalah nilai perbandingan antara hasil pengukuran suatu parameter dengan baku mutunya.

Nilai Indeks Pencemaran diperoleh dari nilai $\mathrm{Ci} / \mathrm{Li}$ maksimum dan $\mathrm{Ci} / \mathrm{Li}$ rata-rata yang dimasukkan ke dalam persamaam rumus 1 (halaman 4). Ci/Li maksimum merupakan nilai $\mathrm{Ci} / \mathrm{Li}$ terbesar. Oleh karena itu parameter yang memiliki nilai $\mathrm{Ci} / \mathrm{Li}$ terbesar dianggap sebagai parameter dominan dalam menentukan nilai status mutu air dibandingkan dengan parameter-parameter lainnya yang diukur.

Di bawah ini merupakan rekapitulasi nilai $\mathrm{Ci} / \mathrm{Li}$ rata-rata setiap parameter untuk seluruh sungai di Kota Bogor tahun 20152019.

parameter seluruh sungai di Kota Bogor Tabel 2 Rekapitulasi nilai $\mathrm{Ci} / \mathrm{Li}$ rata-rata berdasarkan segmentasi dan musim

\begin{tabular}{lrrrrrr}
\hline \multirow{2}{*}{ Parameter } & \multicolumn{2}{c}{ Hulu } & \multicolumn{2}{c}{ Tengah } & \multicolumn{2}{c}{ Hilir } \\
\cline { 2 - 7 } & \multicolumn{1}{c}{ Hujan } & Kemarau & \multicolumn{1}{c}{ Hujan } & \multicolumn{1}{c}{ Kemarau } & Hujan & \multicolumn{1}{c}{ Kemarau } \\
\hline TDS & 0,09 & 0,103 & 0,103 & 0,108 & 0,094 & 0,106 \\
TSS & 0,5349 & 0,563 & 0,4913 & 0,513 & 0,4989 & 0,61 \\
pH & 0,209 & 0,278 & 0,215 & 0,201 & 0,235 & 0,179 \\
BOD & $2,704^{\star *}$ & $2,916^{* *}$ & $2,904^{* *}$ & $3,075^{\star * *}$ & $3,108^{*}$ & $3,263^{* *}$
\end{tabular}




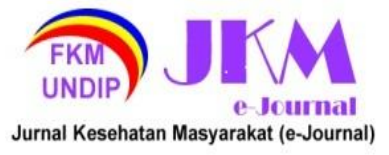

\begin{tabular}{lrrrrrr} 
COD & 0,774 & 0,753 & 0,862 & 0,932 & 0,832 & 0,898 \\
DO & 0,615 & 0,521 & 0,668 & 0,526 & 0,649 & 0,515 \\
Fosfat & $3,628^{\star}$ & $3,276^{\star}$ & $2,967^{*}$ & $3,271^{\star *}$ & $2,531^{\star * *}$ & $2,919^{\star \star *}$ \\
Nitrat & 0,198 & 0,144 & 0,222 & 0,218 & 0,209 & 0,188 \\
Nitrit & $1,828^{\star \star *}$ & $2,515^{\star \star \star}$ & $2,596^{\star * *}$ & $3,935^{\star}$ & $2,813^{\star *}$ & $4,16^{\star}$ \\
Fecal coliform & 0,19 & 0,616 & 0,16 & 0,67 & 0,172 & 0,631 \\
Total coliform & 0,312 & 1,294 & 0,289 & 1,346 & 0,333 & 1,301 \\
\hline
\end{tabular}

Keterangan :

* Nilai Ci/Li terbesar pertama

Dari tabel 2 diketahui bahwa tiga nilai $\mathrm{Ci} / \mathrm{Li}$ terbesar rata-rata dimiliki oleh parameter BOD, fosfat, dan nitrit, baik berdasarkan segmen maupun musim pengambilan sampel. Oleh karena itu tiga parameter tersebut merupakan parameter dominan dalam menentukan nilai status mutu berdasarkan metode Indeks Pencemaran.

Tabel 3 Rekapitulasi nilai Indeks Pencemaran sungai di Kota Bogor berdasarkan segmentasi dan musim

\begin{tabular}{|c|c|c|c|c|c|}
\hline \multirow[t]{2}{*}{ Sungai } & \multirow{2}{*}{\begin{tabular}{l|l}
\multicolumn{2}{c}{ Hulu } \\
Hujan $\quad$ Kemarau
\end{tabular}} & \multicolumn{2}{|c|}{ Tengah } & \multicolumn{2}{|c|}{ Hilir } \\
\hline & & Hujan & Kemarau & Hujan & Kemarau \\
\hline Ciliwung & 3,772 & 3,572 & 5,165 & 1,932 & 4,405 \\
\hline Cibalok & 3,461 & 2,248 & 5,143 & 3,644 & 4,592 \\
\hline Ciparigi & 3,708 & 4,879 & 5,205 & 3,275 & 4,619 \\
\hline Ciluar & 2,047 & 1,811 & 2,733 & 3,314 & 3,114 \\
\hline Cisadane & 3,748 & 1,877 & 4,651 & 2,823 & 2,794 \\
\hline Cisindangbarang & 2,498 & 3,393 & 3,952 & 2,297 & 2,058 \\
\hline Cipakancilan & 3,256 & 1,504 & 2,057 & 2,083 & 2,686 \\
\hline Cianten & 3,734 & 4,102 & 3,236 & 2,829 & 3,156 \\
\hline Angke & 4,193 & 3,1 & 4,353 & 2,055 & 4,4 \\
\hline Cidepit & $1,687 \div 3,242$ & 2,792 & 2,664 & 2,481 & 2,873 \\
\hline $\begin{array}{l}\text { Nilai rata-rata } \\
\text { musim }\end{array}$ & 3,118 & 2,928 & 3,916 & 2,673 & 3,470 \\
\hline $\begin{array}{l}\text { Nilai rata-rata } \\
\text { segmentasi }\end{array}$ & 3,126 & & & & \\
\hline
\end{tabular}




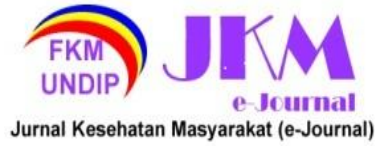

Dari tabel 6 diketahui bahwa nilai Indeks Pencemaran mengalami fluktuasi dari hulu ke hilir. Sementara itu nilai rata-rata nilai Indeks Pencemaran pada musim kemarau lebih besar dibandingkan pada musim hujan sehingga status mutu air sungai pada musim kemarau lebih buruk dibandingkan musim hujan, baik pada bagian hulu, tengah, maupun hilir.

b. Nilai status mutu berdasarkan segmentasi dan musim dengan metode Storet

Nilai Storet diperoleh berdasarkan hasil pembobotan masing-masing parameter. Nilai bobotnya tertera dalam tabel 1 . Langkah pertama untuk memperoleh nilai akhir Storet ialah menentukan nilai terbesar (maksimum), terkecil (minimum), dan ratarata setiap parameter selama tahun 20152019. Kemudian jika masing-masing nilai tersebut melebihi baku mutu, maka diberikan bobot nilai berdasarkan jenis parameternya (fisika, kimia, atau biologi). Selanjutnya dilakukan penjumlahan terhadap bobot nilai tersebut untuk memperoleh skor Storet per parameter.

Tabel 4 di bawah ini merupakan rekapitulasi skor Storet per parameter tersebut. Dari tabel 4 tersebut dapat diketahui bahwa parameter yang memiliki skor 0 merupakan parameter yang nilainya tidak pernah melebihi baku mutu. Berdasarkan hal tersebut tampak bahwa parameter TDS tidak pernah melebihi baku mutu, baik berdasarkan segmen maupun musim. Sementara itu parameter BOD, total fosfat, dan nitrit merupakan parameter yang paling sering melebihi baku mutu, baik pada segmen hulu, tengah, maupun hilir serta pada musim hujan maupun kemarau. Kemudian parameter fecal coliform dan total coliform lebih sering melebihi baku mutu di musim kemarau dibandingkan musim hujan.
Volume 9, Nomor 5, September 2021

http://ejournal3.undip.ac.id/index.php/jkm 


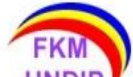

UNDIP)

e-Journal
JURNAL KESEHATAN MASYARAKAT (e-Journal)

Volume 9, Nomor 5, September 2021

ISSN: 2715-5617 / e-ISSN: 2356-3346

http://ejournal3.undip.ac.id/index.php/jkm

Tabel 4 Rekapitulasi nilai Storet sungai di Kota Bogor tahun 2015-2019 per parameter

\begin{tabular}{|c|c|c|c|c|c|c|c|c|c|c|c|c|c|c|c|c|c|c|c|c|c|}
\hline \multirow[t]{2}{*}{ Sungai } & \multicolumn{2}{|c|}{ TDS } & \multicolumn{2}{|c|}{ TSS } & $\mathrm{pH}$ & \multicolumn{2}{|c|}{ BOD } & \multicolumn{2}{|c|}{ COD } & \multicolumn{4}{|c|}{ DO Fosfat } & \multicolumn{2}{|c|}{ Nitrat } & \multicolumn{2}{|c|}{ Nitrit } & \multicolumn{2}{|c|}{ Fecal coli } & \multicolumn{2}{|c|}{ Total coli } \\
\hline & $\mathbf{H}$ & $\mathbf{K}$ & $\mathbf{H}$ & $\mathbf{K}$ & H K & $\mathbf{H}$ & $\mathrm{K}$ & $\mathbf{H}$ & $\mathbf{K}$ & $\mathbf{H}$ & $\mathrm{K}$ & $\mathbf{H}$ & $\mathbf{K}$ & $\mathbf{H}$ & $\mathbf{K}$ & $\mathbf{H}$ & $\mathbf{K}$ & $\mathbf{H}$ & $\mathbf{K}$ & $\mathbf{H}$ & $\mathbf{K}$ \\
\hline Ciliwung hulu & 0 & 0 & 0 & 0 & 0 & -16 & -16 & -4 & 0 & 0 & 0 & -16 & -16 & 0 & 0 & 0 & -4 & 0 & -6 & 0 & -6 \\
\hline Cibalok hulu & 0 & 0 & -2 & 0 & 0 & -16 & -16 & 0 & 0 & 0 & 0 & -16 & -16 & 0 & 0 & 0 & -4 & 0 & -6 & 0 & -24 \\
\hline Ciparigi hulu & 0 & 0 & 0 & 0 & 0 & -16 & -20 & 0 & -4 & -4 & -4 & -16 & -16 & 0 & 0 & -16 & -16 & -6 & -6 & 0 & -24 \\
\hline Ciluar hulu & 0 & 0 & -2 & 0 & 0 & -16 & -16 & 0 & -4 & 0 & 0 & -4 & -16 & 0 & 0 & -16 & -16 & -6 & 0 & -24 & 0 \\
\hline Cisadane hulu & 0 & 0 & -2 & 0 & 0 & -16 & -16 & -4 & -4 & 0 & 0 & -16 & -16 & 0 & 0 & 0 & -4 & 0 & -6 & 0 & -24 \\
\hline Cisindangbarang hulu & 0 & 0 & 0 & 0 & 0 & -16 & -20 & -4 & 0 & -4 & -4 & -16 & -16 & 0 & 0 & -16 & -16 & 0 & -6 & 0 & -24 \\
\hline Cipakancilan hulu & 0 & 0 & -2 & -2 & 0 & -16 & -16 & 0 & -4 & 0 & 0 & -16 & -16 & 0 & 0 & 0 & -16 & 0 & -6 & 0 & -24 \\
\hline Cianten hulu & 0 & 0 & 0 & -2 & 0 & -16 & -20 & 0 & 0 & -4 & -4 & -16 & -16 & 0 & 0 & -16 & -16 & 0 & -6 & 0 & -24 \\
\hline Angke hulu & 0 & 0 & -2 & -2 & 0 & -20 & -20 & -16 & -4 & -4 & -4 & -16 & -16 & 0 & 0 & -4 & -16 & 0 & -6 & 0 & -24 \\
\hline Cidepit hulu & 0 & 0 & -2 & -2 & 0 & -16 & -20 & 0 & -4 & -4 & -4 & -16 & -16 & 0 & 0 & 0 & -16 & 0 & -6 & 0 & -24 \\
\hline Ciliwung tengah & 0 & 0 & -2 & 0 & 0 & -16 & -16 & -4 & 0 & 0 & 0 & -16 & -16 & 0 & 0 & -16 & -16 & 0 & -6 & 0 & -24 \\
\hline Cibalok tengah & 0 & 0 & 0 & -2 & 0 & -16 & -16 & -4 & -4 & -4 & 0 & -16 & -16 & 0 & -4 & -16 & -16 & 0 & -6 & 0 & -24 \\
\hline Ciparigi tengah & 0 & 0 & 0 & 0 & 0 & -16 & -16 & 0 & -16 & -4 & 0 & -4 & -16 & 0 & 0 & -16 & -16 & -6 & 0 & -24 & 0 \\
\hline Ciluar tengah & 0 & 0 & -2 & 0 & 0 & -16 & -16 & -4 & 0 & 0 & -4 & -16 & -16 & 0 & 0 & -4 & -16 & 0 & -6 & 0 & -24 \\
\hline Cisadane tengah & 0 & 0 & 0 & 0 & 0 & -16 & -20 & -4 & -4 & -4 & -4 & -16 & -16 & 0 & 0 & -16 & -16 & 0 & -6 & 0 & -24 \\
\hline Cisindangbarang tengah & 0 & 0 & -2 & -8 & 0 & -16 & -16 & 0 & 0 & 0 & 0 & -16 & -16 & 0 & 0 & -16 & -16 & 0 & -6 & 0 & -24 \\
\hline Cipakancilan tengah & 0 & 0 & -2 & -2 & 0 & -16 & -20 & -16 & -16 & -16 & -4 & -16 & -16 & 0 & 0 & -16 & -4 & 0 & -6 & 0 & -24 \\
\hline Cianten tengah & 0 & 0 & 0 & -2 & 0 & -16 & -16 & 0 & -4 & 0 & 0 & -16 & -16 & 0 & 0 & -16 & -16 & 0 & -6 & 0 & -24 \\
\hline Angke tengah & 0 & 0 & -2 & -2 & 0 & -20 & -20 & -4 & -4 & -4 & -4 & -16 & -16 & 0 & 0 & -16 & -16 & 0 & -6 & 0 & -24 \\
\hline Cidepit tengah & 0 & 0 & -2 & 0 & $0 \quad 0$ & -16 & -16 & -4 & 0 & 0 & 0 & -16 & -16 & 0 & 0 & -16 & -16 & 0 & -6 & 0 & -24 \\
\hline Ciliwung hilir & 0 & 0 & 0 & -2 & 00 & -16 & -16 & -4 & -4 & 0 & 0 & -16 & -16 & 0 & 0 & -16 & -16 & 0 & -6 & 0 & -6 \\
\hline
\end{tabular}


Tabel 4 Rekapitulasi skor Storet sungai di Kota Bogor tahun 2015-2019 per parameter (lanjutan)

\begin{tabular}{|c|c|c|c|c|c|c|c|c|c|c|c|c|c|c|c|c|c|c|c|c|}
\hline \multirow[t]{2}{*}{ Sungai } & \multicolumn{2}{|c|}{ TDS } & TSS & $\mathrm{pH}$ & \multicolumn{2}{|c|}{ BOD } & \multicolumn{2}{|c|}{ COD } & \multicolumn{2}{|c|}{ DO } & \multicolumn{2}{|c|}{ Fosfat } & \multicolumn{2}{|c|}{ Nitrat } & \multicolumn{2}{|c|}{ Nitrit } & \multicolumn{2}{|c|}{ Fecal coli } & \multicolumn{2}{|c|}{ Total coli } \\
\hline & $\mathbf{H}$ & $\mathbf{K}$ & H K & $\mathrm{H}$ & K H & K & H & K & H & K & $\mathbf{H}$ & K & $\mathbf{H}$ & K & $\mathbf{H}$ & $\mathrm{K}$ & $\mathbf{H}$ & $\mathbf{K}$ & $\mathbf{H}$ & $\mathbf{K}$ \\
\hline Cibalok hilir & 0 & 0 & -2 & 0 & $0-16$ & -16 & -4 & 0 & 0 & 0 & -16 & -16 & 0 & 0 & -16 & -16 & 0 & -6 & 0 & -24 \\
\hline Ciparigi hilir & 0 & 0 & 00 & 0 & -16 & -16 & -4 & -4 & -4 & -4 & -16 & -16 & 0 & 0 & -16 & -16 & 0 & -6 & 0 & -24 \\
\hline Ciluar hilir & 0 & 0 & $0-2$ & 0 & -20 & -16 & -16 & -4 & -4 & -4 & -16 & -16 & 0 & 0 & -16 & -16 & -6 & 0 & -24 & 0 \\
\hline Cisadane hilir & 0 & 0 & $-2-8$ & 0 & -20 & -16 & 0 & -4 & -4 & 0 & -16 & -16 & & 0 & -16 & -16 & 0 & -6 & 0 & -24 \\
\hline Cisindangbarang hilir & 0 & 0 & $0 \quad 0$ & 0 & -16 & -20 & 0 & -4 & 0 & 0 & -16 & -16 & & 0 & -16 & -16 & 0 & -6 & 0 & -24 \\
\hline Cipakancilan hilir & 0 & 0 & $\begin{array}{ll}-2 & -2\end{array}$ & 0 & -16 & -20 & -4 & -4 & 0 & 0 & -16 & -16 & 0 & 0 & -16 & -16 & 0 & -6 & 0 & -24 \\
\hline Cianten hilir & 0 & 0 & -2 & 0 & -20 & -20 & -4 & -16 & -4 & -4 & -16 & -16 & 0 & 0 & -16 & -16 & 0 & -6 & 0 & -24 \\
\hline Angke hilir & 0 & 0 & 0 & 0 & -16 & -16 & -4 & -4 & 0 & -4 & -16 & -16 & 0 & 0 & -16 & -16 & 0 & -6 & 0 & -24 \\
\hline Cidepit hilir & 0 & 0 & -8 & 0 & $0 \begin{array}{ll}0 & -20\end{array}$ & -20 & -4 & -4 & 0 & -4 & -16 & -16 & 0 & 0 & -16 & -1 & 0 & -6 & 0 & -24 \\
\hline Cibalok hilir & 0 & 0 & -2 & 0 & $0-16$ & -16 & -4 & 0 & 0 & 0 & -16 & -16 & 0 & 0 & -16 & -16 & 0 & -6 & 0 & -24 \\
\hline
\end{tabular}

Keterangan:

$\mathrm{H}=$ Musim hujan

$\mathrm{K}=$ Musim kemarau

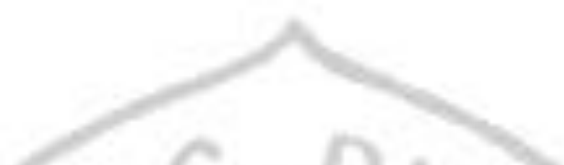




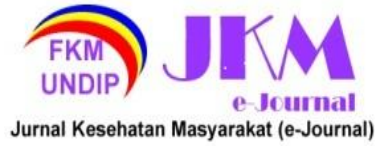

Selanjutnya skor Storet per parameter tersebut dijumlahkan berdasarkan segmentasi dan musim untuk memperoleh skor akhir Storet. Skor akhir inilah yang akan dianalisis lebih lanjut untuk
JURNAL KESEHATAN MASYARAKAT (e-Journal)

Volume 9, Nomor 5, September 2021

ISSN: 2715-5617 / e-ISSN: 2356-3346

http://ejournal3.undip.ac.id/index.php/jkm

Tabel 5 Rekapitulasi skor akhir Storet sungai di Kota Bogor berdasarkan segmentasi dan musim

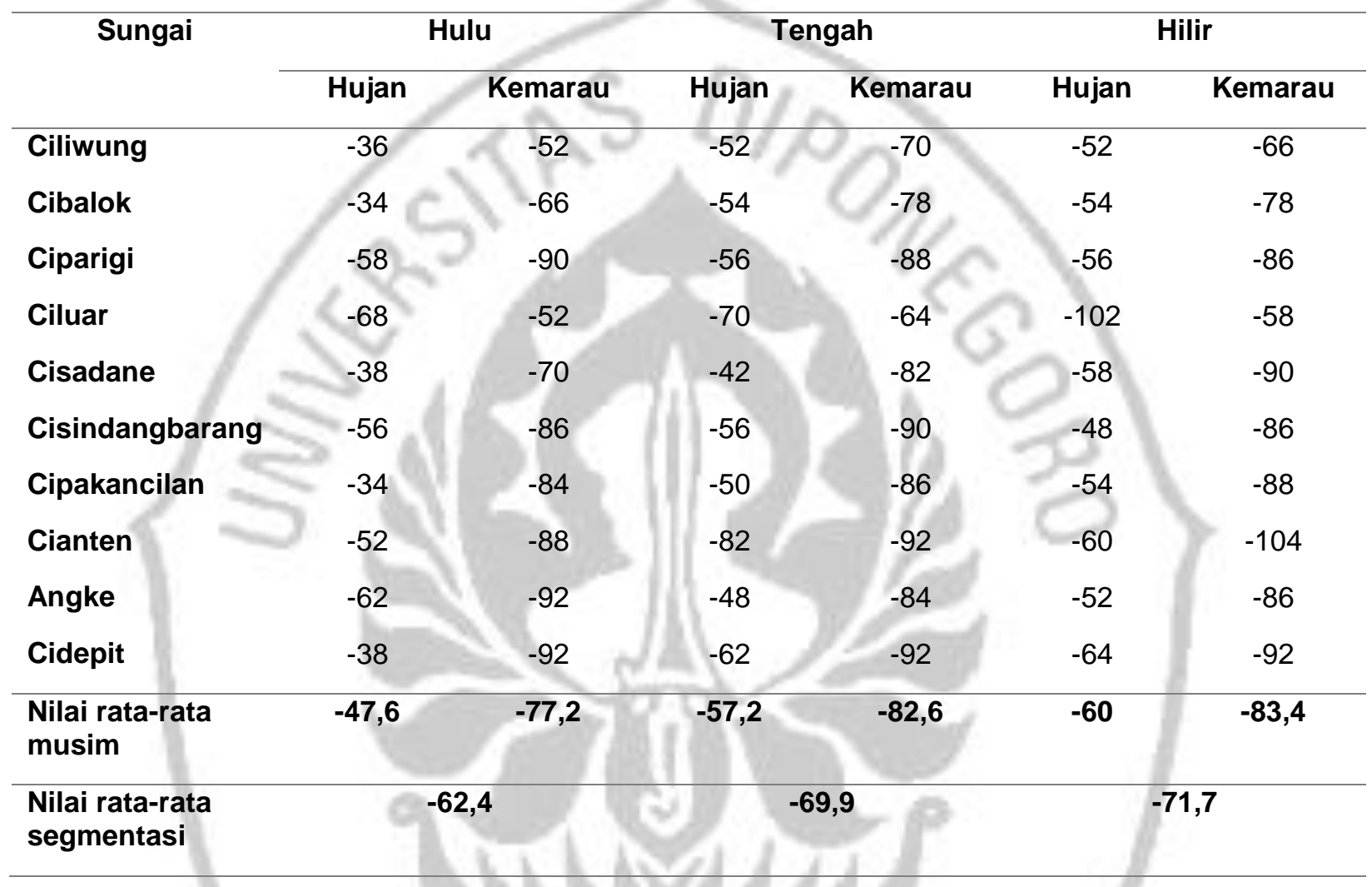

Dari tabel 5 diketahui bagian hulu sungai memiliki status mutu paling baik dan bagian hilir paling buruk karena nilai Storetnya paling kecil. Berdasarkan musim, rata-rata nilai Storet pada musim kemarau lebih kecil mengetahui perbedaan nilainya berdasarkan segmentasi dan musim. Berikut ini merupakan rekapitulasi skor akhir Storet setiap sungai di Kota Bogor.

Tabel 6 Hasi uji bivariat skor akhir Storet sungai di Kota Bogor tahun 2015-2019 berdasarkan segmentasi dan musim

\begin{tabular}{ccccc}
\hline Variabel & \multicolumn{2}{c}{ Kelompok Sampel } & Nilai $\mathbf{p}$ & Interpretasi \\
\hline \multirow{3}{*}{ Segmentasi } & Hulu & & \\
& Musim hujan & Tengah & $0,252^{*}$ & Tidak signifikan \\
& & &
\end{tabular}




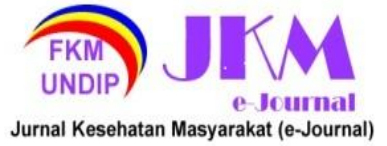

$\begin{array}{cccc} & \text { Hulu } & & \\ \text { Musim kemarau } & \text { Tengah } & 0,817^{*} & \text { Tidak signifikan } \\ & \text { Hilir } & & \end{array}$

Hulu

Musim hujan

Musim kemarau

Musim

Tengah

Keterangan:

* Uji Kruskal Wallis

** Uji Wilcoxon

*** Uji Paired Sample T-test

Dari tabel 6 diketahui bahwa tidak terdapat perbedaan yang signifikan antara nilai Indeks Pencemaran pada bagian hulu, tengah, dan hilir sungai, baik pada musim kemarau maupun hujan karena nilai probabilitas (sig) > 0,05. Berdasarkan musim, terdapat perbedaan yang signifikan antara nilai Storet di musim hujan dan kemarau pada segmen hulu dan tengah serta tidak terdapat perbedaan yang signifikan pada segmen hilir.

Pada metode Storet, nilai parameter yang diperoleh dari hasil pengujian sampel akan dikategorikan menjadi dua kelompok, yaitu di bawah baku mutu atau melebihi baku mutu. Berapapun nilai parameter yang diperoleh dari hasil pengujian sampel tersebut, jika nilainya melebihi baku mutu maka akan diberikan skor yang sama. Begitupun pada parameter yang tidak melebihi baku mutu, semuanya akan diberi skor nol.

Dari tabel 4 diketahui bahwa parameter yang melebihi baku mutu (memperoleh skor selain nol) antara segmen hulu, tengah, dan
Volume 9, Nomor 5, September 2021

ISSN: 2715-5617 / e-ISSN: 2356-3346

http://ejournal3.undip.ac.id/index.php/jkm

Hulu

Hilir

$0,008^{* *} \quad$ Signifikan

Signifikan

$0,001^{* * *}$

$0,066^{* *}$

Tidak signifikan hilir setiap sungai tidak berbeda jauh. Oleh karena itu skor akhir Storet yang dihasilkan di antara ketiga segmen tersebut tidak berbeda secara signifikan satu sama lain.

Dari tabel 4 diketahui pula bahwa parameter yang paling sering melebihi baku mutu pada musim kemarau dibandingkan musim hujan adalah parameter mikrobiologi (fecal coliform dan total coliform). Parameter mikrobiologi pada metode Storet memiliki bobot terbesar dibandingkan dengan parameter fisika dan kimia. Ketika suatu badan air memiliki nilai mikrobiologi yang melebihi baku mutu, nilai Storetnya pun akan berubah secara drastis dibandingkan ketika parameter mikrobiologi tidak melebihi baku mutu atau tidak diikutsertakan dalam perhitungan. Oleh karena itu nilai status mutu pada musim kemarau jauh berbeda dibandingkan dengan musim hujan dikarenakan nilai parameter mikrobiologi pada musim hujan lebih sering berada di bawah baku mutu sehingga bobot nilainya nol. 


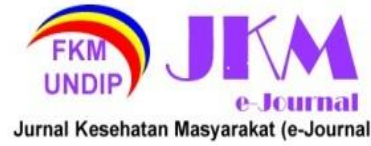

Jurnal Kesehatan Masyarakat (e-Journal)
JURNAL KESEHATAN MASYARAKAT (e-Journal)

Volume 9, Nomor 5, September 2021

ISSN: 2715-5617 / e-ISSN: 2356-3346

http://ejournal3.undip.ac.id/index.php/jkm

Tabel 7 Hasi uji bivariat untuk nilai Indeks Pencemaran sungai di Kota Bogor tahun 2015-2019 berdasarkan segmentasi dan musim

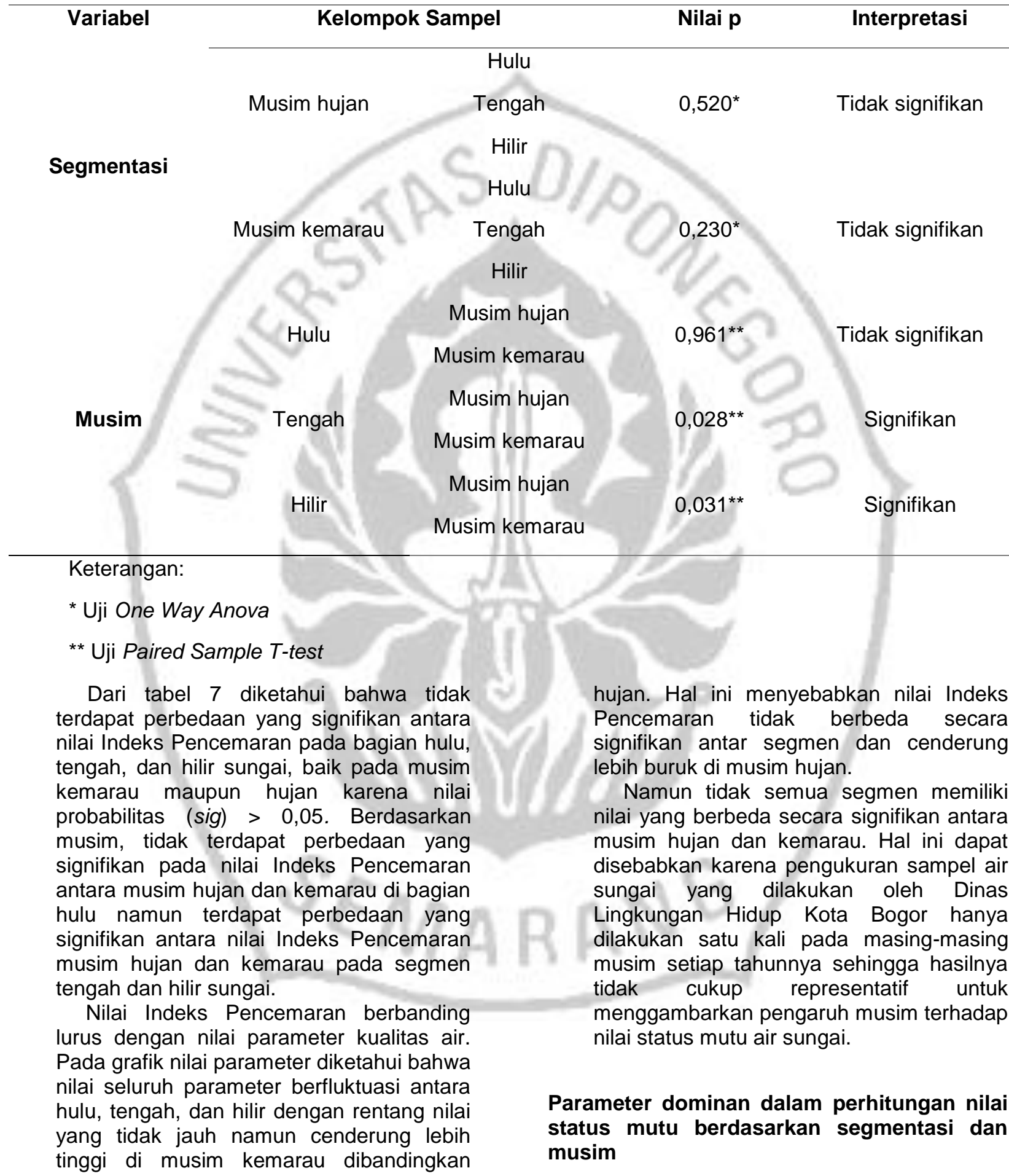




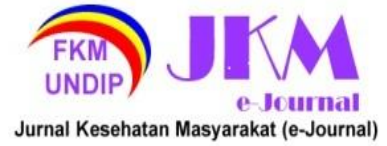

Pada perhitungan nilai Storet dan Indeks Pencemaran berdasarkan segmentasi, parameter BOD, total fosfat, dan nitrit merupakan parameter yang paling sering melebihi baku mutu dan memiliki nilai $\mathrm{Ci} / \mathrm{Li}$ terbesar. Oleh karena itu ketiganya merupakan parameter dominan berdasarkan segmentasi.

BOD, fosfat, dan nitrit merupakan parameter indikator pencemaran bahan organik. Menurut Badan Perencana Lingkungan Hidup (BPLH) Kota Bogor, sumber utama pencemaran sungai ialah limbah rumah tangga yang didominasi oleh bahan organik milik warga di sekitar aliran sungai. Bahan organik yang masuk ke dalam air akan diuraikan oleh bakteri dengan memanfaatkan oksigen terlarut. ${ }^{15}$ Semakin banyak bahan organik yang harus diuraikan, maka semakin banyak pula oksigen yang dibutuhkan bakteri sehingga kadar oksigen terlarut dalam air semakin berkurang.

Fosfat dan nitrit merupakan zat yang sering ditemukan pada pupuk. ${ }^{16}$ Diketahui bahwa mayoritas penggunaan lahan di sepanjang DAS Ciliwung dan Cisadane yang masuk ke dalam wilayah administrasi Kota Bogor digunakan untuk pertanian dan pemukiman. Hal ini dimungkinkan menjadi salah satu sumber pencemaran fosfat dan nitrat dalam air sungai selain limbah organik masyarakat.

Parameter fecal coliform dan total coliform lebih sering melebihi baku mutu di musim kemarau. Pada metode Storet, parameter mikrobiologi memiliki bobot nilai terbesar. Parameter ini juga memiliki rentang nilai yang cukup jauh antara musim hujan dan kemarau (lebih tinggi di musim kemarau) sehingga dapat dikatakan sebagai parameter dominan dalam perhitungan status mutu berdasarkan musim.

Tingginya kadar parameter mikrobiologi pada musim kemarau dibandingkan hujan dapat disebabkan karena laju limpasan air pada musim hujan lebih tinggi sehingga bakteri lebih mudah tersapu oleh aliran air sungai sementara pada musim kemarau bakteri tersebut dapat mengendap dan berkembangbiak dengan baik. ${ }^{17}$

Menurut Laporan Akhir Kajian Lingkungan Hidup Strategis Kota Bogor, satu dari dua puluh penduduk Kota Bogor masih melakukan $B A B$ di area terbuka seperti sungai dan drainase. Selain itu baru sekitar $64,05 \%$ tempat penyaluran akhir tinja milik warga yang disalurkan ke tangki septik dan sekitar 23,98\%nya langsung dialirkan ke sungai/drainase. ${ }^{18}$

\section{KESIMPULAN}

Nilai status mutu sungai di Kota Bogor tahun 2015-2019 tidak berbeda secara signifikan berdasarkan segmentasi, baik dengan metode Storet maupun Indeks Pencemaran. Nilai status mutu sungai di Kota Bogor tahun 2015-2019 berbeda secara signifikan berdasarkan musim pada segmen hulu dan tengah serta tidak berbeda secara signifikan pada segmen hilir menurut metode Storet. Nilai status mutu tidak berbeda secara signifikan berdasarkan musim pada segmen hulu namun berbeda secara signifikan pada segmen tengah dan hilir menurut metode Indeks Pencemaran. Parameter dominan pada status mutu berdasarkan segmentasi yaitu BOD, total fosfat, dan nitrit, sedangkan berdasarkan musim yaitu fecal coliform dan total coliform.

\section{SARAN}

Bagi DLH Kota Bogor diharapkan dapat bekerjasama dengan instansi terkait untuk membangun Instalasi Pengolahan Air Limbah (IPAL) komunal di sekitar bantaran sungai dan dapat melakukan pengukuran parameter kualitas air sungai pada berbagai variasi waktu dalam satu musim.

Bagi masyarakat diharapkan masyarakat di sekitar bantaran sungai membangun septic tank agar buangan tinja tidak mencemari air sungai. Jika lahan tidak memadai maka dapat dibangun septic tank komunal dari swadaya masyarakat.

Bagi peneliti lain diharapkan dapat menggunakan parameter yang lebih banyak dan bervariasi agar diperoleh gambaran yang lebih mendetail mengenai kualitas air sungai di Kota Bogor.

\section{DAFTAR PUSTAKA}

1. Dinas Lingkungan Hidup Kota Bogor Dokumen Informasi Kinerja Pengelolaan Lingkungan Hidup Daerah Kota Bogor Tahun 2017. Bogor; 2017.

2. Dinas Lingkungan Hidup Kota Bogor. Laporan Dokumen Informasi Kinerja Pengelolaan Lingkungan Hidup Daerah 


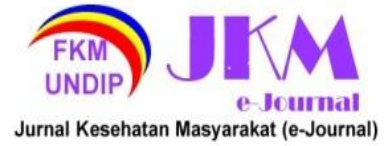

Tahun 2016 Kota Bogor. Bogor; 2016.

3. Dinas Lingkungan Hidup Kota Bogor. Laporan Kualitas Air Sungai dan Situ Kota Bogor Semester 1 Tahun 2020. Bogor; 2020.

4. Yananto A, Sibarani RM. Analisis kejadian El-Nino dan pengaruhnya terhadap intensitas curah hujan di wilayah Jabodetabek (studi kasus: periode puncak musim hujan tahun 2015/2016). JSTMC. 2016;17(2):65.

5. Permatasari R. Pengaruh perubahan penggunaan lahan terhadap rezim hidrologi DAS (studi kasus: DAS Komering). JTS ITB. 2017;24(1):91-8.

6. Kementerian Lingkungan Hidup dan Kehutanan Republik Indonesia. Indeks Kualitas Lingkungan Hidup tahun 2018. Pusdatin KemenLHK. Jakarta; 2018.

7. Kementerian PPN Republik Indonesia. Rencana Pembangunan Jangka Menengah Nasional 2015-2019. Rencana Pembangunan Jangka Menengah Nasional 2020-2024 Jakarta; 2019.

8. Vikrama Karya Persero Engineering and Management Consultant. Panduan aplikasi kualitas air. In: Water Resources and Irrigation Sector Management Project II (WISMP-2) -Basin Water Resources Management (BWRM). Jakarta Selatan: Direktorat Bina Operasi dan Pemeliharaan-Dirjen Sumberdaya Air-Kementerian Pekerjaan Umum RI; 2017. p. 55.

9. Nasution L. Google earth pro [Internet]. Google Inc; 2020. Available from: https://www.google.com/int//id/earth/dow nload/gep/agree.html

10. Menteri Negara Lingkungan Hidup. Keputusan Menteri Negara Lingkungan Hidup Nomor 115 Tentang Pedoman Penentuan Status Mutu Air. Indonesia; 2003.

11. Mei K, Liao L, Zhu Y, Lu P, Wang Z, Dahlgren RA, et al. Evaluation of spatialtemporal variations and trends in surface water quality across a rural-suburbanurban interface. Environ Sci Pollut Res. 2014;21(13):8036-51.

12. Anonim. Self-purification ability of water system [Internet]. Deledan. 2019 [cited
2021 Mar 3]. Available from:

https://water-

detective.net/teachers/guidebooks/how-

can-a-river-clean-itself/self-purification-

processes-in-rivers/\#chapter-6-

background-information

13. Wang $X$, Cheng L, Liang $Y$, Lai WH, Miao $Z$, Chou SL, et al. Public Health, Environmental and Social Determinants of Health (PHE). J Electron Spectros Relat Phenomena [Internet]. 2017;14(3):294-9. Available from: http://www.who.int/phe/news/PHEeNews-93-JuneJuly2017.pdf\%0Ahttp://dx.doi.org/10.101 6/j.electacta.2012.01.094\%0Ahttps://ww w.pca.state.mn.us/sites/default/files/wqiw3-

12.pdf\%OAhttps://doi.org/10.1080/20550 324.2017.1329983\%0Ahttps://fas.org/sg $\mathrm{p} / \mathrm{crs} / \mathrm{misc} / \mathrm{R}$

14. Fondriest Environmental. Water temperature [Internet]. Fundamentals of Environmental Measurements. 2014 [cited 2021 Jan 1]. Available from: https://www.fondriest.com/environmentalmeasurements/parameters/waterquality/water-temperature/

15. Yuningsih HD, Anggoro S, Soedarsono $P$. Hubungan bahan organik dengan produktivitas perairan pada kawasan tutupan eceng gondok, perairan terbuka, dan keramba jaring apung di Rawa Pening Kabupaten Semarang Jawa Tengah. MAQUARES. 2014;3(1):37-43.

16. United States Environmental Protection Agency. Nutrients pollutions: sources and sollutions [Internet]. The Issue. 2019 [cited 2020 Dec 11]. Available from: https://www.epa.gov/nutrientpollution/sou rces-and-solutions

17. Fuentes-Rivas RM, Martínez-Alva G, Ramos-Leal JA, de León GSC, MoranRamírez J, de Oca RMGFM. Assessment of contamination by anthropogenic dissolved organic matter in the aquifer that underlies the agricultural area. Springer. Springer; 2020.

18. Dinas Lingkungan Hidup Kota Bogor. Kajian Lingkungan Hidup Strategis. Bogor; 2014. 